TAPROBANICA, ISSN 1800-427X. October, 2011. Vol. 03, No. 02: pp. 104-106.

(C) Taprobanica Private Limited, Jl. Kuricang 18 Gd.9 No.47, Ciputat 15412, Tangerang, Indonesia.

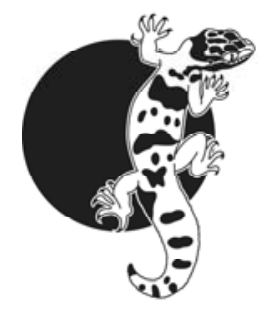

\section{First Report of a Cerambycid beetle (Capnolymma cingalensis) from India}

Lepturinae are a group of Cerambycidae that can be recognized by their peculiar form, especially the head being prolonged behind into a 'neck' (Pascoe, 1869).

Genus Capnolymma was described by Pascoe with Capnolymma stygia from Borneo as the type species. In his epic work, better known as "Longicornia Malayana” Pascoe (1869) gave full diagnosis of the genus in Latin. In brief, these characters are: "head elongated, mandibles produced, eyes coarsely facetted and rounded; antennae situated away from the eyes and longer than the body, scape elongated and apically swollen, segments 3-4 short but rest long and subequal; prothorax campanuliform, laterally subtuberculate to dentate; elytra short, broader at base than prothorax; legs long, femora fusiform”

Gahan (1906) also gave a detailed description of the genus Capnolymma and also described Capnolymma cingalensis, as a new species (along with illustration) from Ceylon (now Sri Lanka) in the 'Fauna of British India' volume. Some important characters of the species are: "body brown, varying to reddish brown on abdomen, legs and disc of the elytra; covered with dark grey pubescence (see Fig.1); prothorax brownish above, marked with some lines of ashy - white pubescence - one median, dividing just before the middle so as to enclose a lozenge- shaped area from the lateral angles of which two slightly curved lines run backwards about halfway to the base of prothorax; antennae of male more than half as long as body (see Fig. 2 \& 3); prothorax finely rugulose-punctate; scutellum covered with dense white pubescence; elytra closely and rather strongly punctured; its apices truncate and unarmed. Total length $14 \mathrm{~mm}$, breadth $5 \mathrm{~mm}$, Hab. Ceylon”. Fig. 4 shows more or less rounded, coarsely facetted eyes.

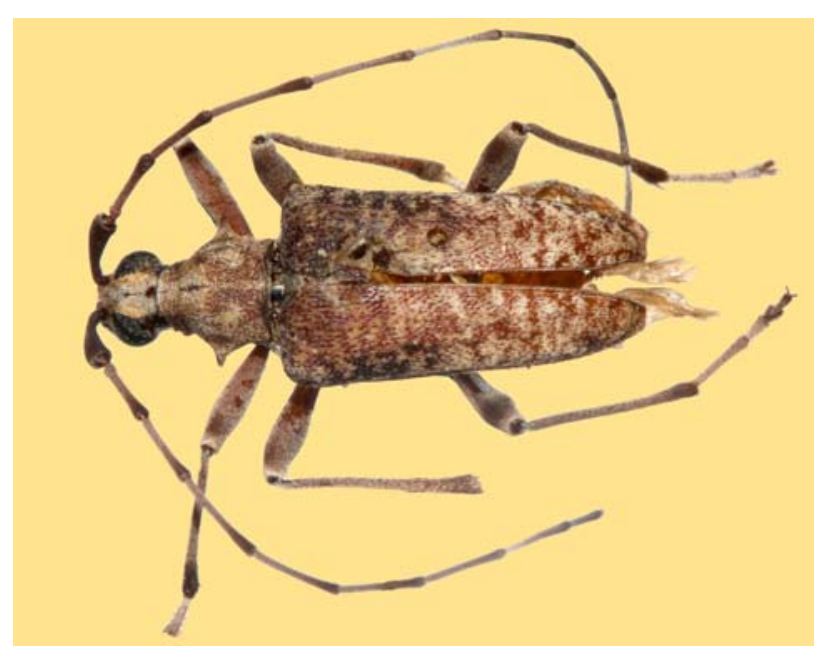

Fig. 1: Dorsal view of Capnolymma cingalensis, note the overall Lepturinae habitus

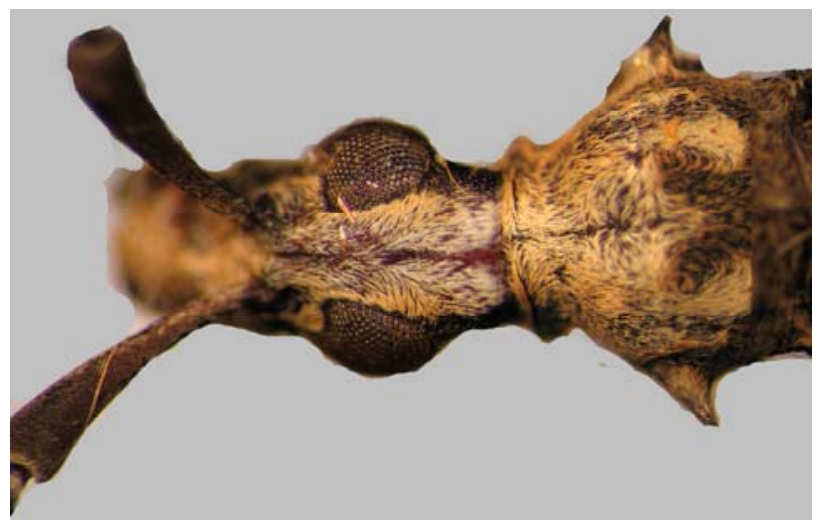

Fig. 2: Close up of head and prothorax of Capnolymma to show pubescence pattern

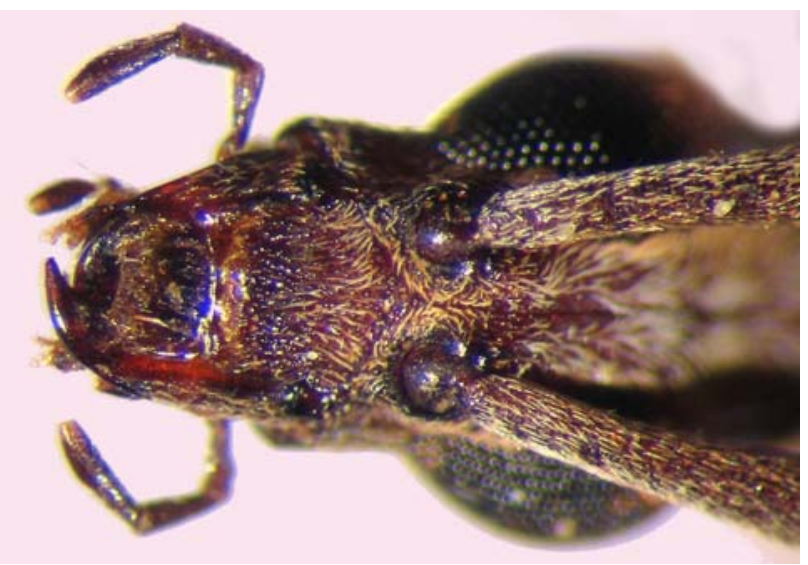

Fig. 3: Close up of head in frontal view of Capnolymma 


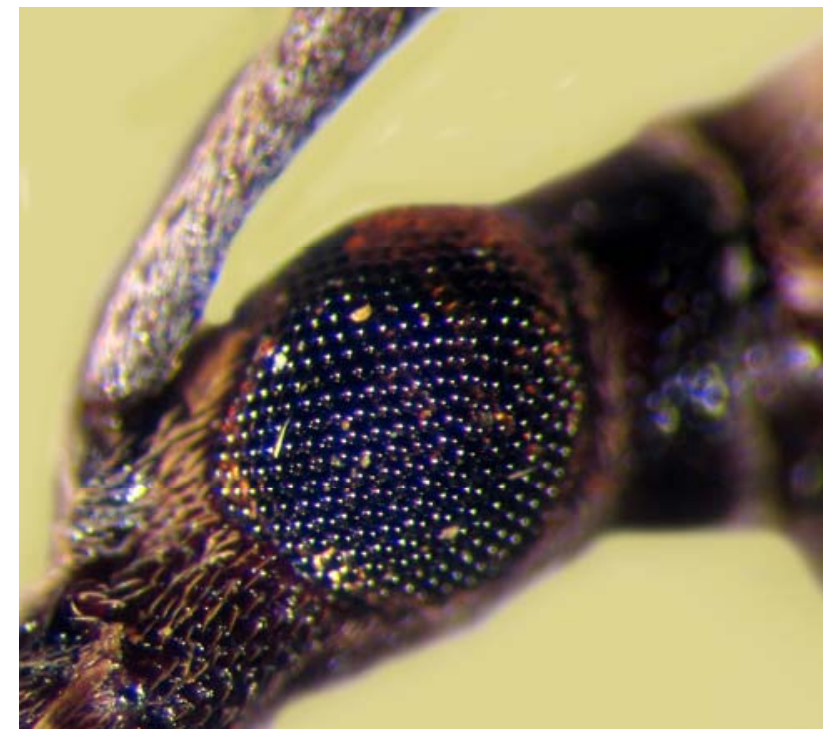

Fig. 4: Close up of eye of Capnolymma showing coarse facets

Subsequent to Pascoe (1869), Gressitt \& Rondon (1970) divided the genus into two subgenera Capnolymma (sensu stricto) and Acapnolymma (Gressitt \& Rondon, 1970). Ohbayashi (1994) presented a taxonomic study of the genus Capnolymma with compilation of seven described species, also added two new species and provided diagnostic key for all the species. A detailed study of the species Acapnolymma sulcaticeps Pic, prompted Vives (2003) to consider Acapnolymma as a separate genus rather than a subgenus of Capnolymma. With the removal of subgenus Acapnolymma, and with the addition of another species by Holzschuh (2006), the total number of species under Capnolymma stands at nine. The genus was placed in the tribe Xylosteini of the subfamily Lepturinae by Gahan (1906). Recent 'Catalog and Bibliography of Longhorned Beetles from Borneo' by Heffern (2005) also maintains this position. Both, Lepturinae and Xylosteini, are currently valid names, as per the 'Catalogue of Family-Group Names in Cerambycidae (Coleoptera)' (Bousquet et al., 2009). It may be noted here that some people have suggested that Capnolymma be included in the subfamily Dorcasominae and the tribe Dorcasomini (Ozdikmen, 2008).

Following species of Capnolymma are known at present: C. stygia Pascoe, 1858 (type of the genus); C. cingalensis Gahan, 1906; C. capreola Pascoe, 1866; C. similis Gressitt \& Raodon, 1970; C. laotica Gressitt \& Rondon, 1970; C. brunnea Gressitt \& Rondon, 1970; C. ishiharai Ohbayashi, 1994; C. borneana Ohbayashi, 1994 and C. ohbayashii Holzschuh, 2006.

We had the opportunity to study four specimens of Capnolymma cingalensis, collected in Karnataka State. At least two specimens were collected in Sandalwood forest and it is therefore likely that Sandal is the host plant. Details of the three specimens studied are given below (see Table 1 for measurements):

Specimen 1: Cat. no. GKVK-CC1; female; Loc. Gandhi Krishi Vignyan Kendra (GKVK), University of Agricultural Sciences, Bangalore, Karnataka; Coll. unknown; Date. 22.VI.1995.

Specimen 2: Cat. no. GKVK-CC2; female; Loc. near Bangalore; Coll. unknown; Date. 10.VI.2004.

Specimen 3: Cat. no. GKVK-CC3; male; Loc. GKVK; Coll. Lokesha; Date. 28.VII.2002.

Table 1: Measurement data of the three Capnolymma cingalensis specimens studied (all measurements are in $\mathrm{mm})$

\begin{tabular}{|l|c|c|c|}
\hline \multicolumn{1}{|c|}{ Specimen Number } & $\mathbf{1}$ & $\mathbf{2}$ & $\mathbf{3}$ \\
\hline Total length & 17.4 & 15.7 & 11.3 \\
\hline $\begin{array}{l}\text { Head length } \\
\text { (including Mandibles) }\end{array}$ & 4.2 & 4.0 & 2.8 \\
\hline Breadth at Humerus & 5.3 & 4.4 & 3.0 \\
\hline $\begin{array}{l}\text { Breadth at prothoracic } \\
\text { spine }\end{array}$ & 4.0 & 3.6 & 2.3 \\
\hline $\begin{array}{l}\text { Prothorax length / } \\
\text { breadth }\end{array}$ & $3.2 / 4.0$ & $2.7 / 3.6$ & $2.0 / 2.3$ \\
\hline Elytra length & 10.0 & 9.0 & 6.5 \\
\hline
\end{tabular}

Since the earlier record of the species $C$. cingalensis is only from Sri Lanka also only the original description by Gahan (1906); further, since we are not aware of any further published record of this species, this is the first report of its presence in India. Even Ohbayashi (1994), who studied the genus Capnolymma, also could not get to study this species. Recent checklist of Cerambycidae of Sri Lanka (Makhihara et al., 2008) also mentions C. cingalensis as occurring in Sri Lanka but the authors did not see any specimen. There are no fresh surveys reporting Cerambycidae of Sri Lanka, so the status of this species in Sri Lanka is uncertain.

The species is perhaps established in India now, at least in Western Ghats of south India. Some photos 
of the species are also provided to help naturalists in identification of the species.

\section{Acknowledgements}

The authors are grateful to the authorities of their respective institutions for facilities and encouragements. We thank Carolus Holzschuh (Austria) for confirming identity of our material and for continuous support to first author. We also thank Eduardo Vives (Barcelona, Spain) for providing the photograph of the types at BMNH. We acknowledge financial support from Ministry for Environment \& Forests, New Delhi. We all thank H. M. Yeshwanth for habitus photo. Finally first author thanks to the Board of College and University Development - Pune University for financial support for this study.

\section{Literature cited}

Bousquet, Y., D. J. Heffern, P. Bouchard and E. H. Nearns, 2009. Catalogue of family-group names in cerambycidae (coleoptera). Zootaxa, 2321: 1-80.

Gahan, C. J., 1906. The fauna of British India including Ceylon \& Burma, Coleoptera - Vol. I. Taylor \& Francis, London (Reprint by Today \& Tomorrow’s printers \& publishers, New Delhi): 329.

Gressitt, J. L. and J. A. Rondon, 1970. Cerambycids of Laos (Disteniidae, Prioninae, Philinae, Aseminae, Lepturinae \& Cerambycinae). Pacific Insects Monograph, 24: 1-314.

Heffern, D. J., 2005. Catalog and bibliography of longhorned beetles from Borneo (Coleoptera: Cerambycidae). http://www.zin.ru/animalia/Coleopter a/pdf/borneo_catalog_electronic_version_2005-1.pdf). downloaded on $13^{\text {th }}$ April 2008.

Holzschuh, C., 2006. Beschreibung von 51 neuen borkkaefen aus der palaearktischen und orientalischen region, vorwiegend aus Borneo und China. Entomologica Brasiliensia et Collectionis Frey, 28: 205-276.

Makhihara, H., A. Mannakkara, J. Fujimura and A. Ohtake, 2008. Checklist of longicorn coleoptera of Sri Lanka: Vesperidae and Cerambycidae excluding Lamiinae. Bulletin of Forestry and Forest Products Research Institute, Matsunosato, Japan, 7 (407): 95110.

Ohbayashi, N. 1994. A taxonomic study of the genus Capnolymma, with descriptions of two new species (Coleoptera: Cerambycidae), Transactions of the Shikoku Entomological Society, 20 (3\&4): 271-284.
Ozdikmen, H. 2008. A nomenclatural act: some nomenclatural changes on palaearctic longhorned beetles (Coleoptera: Cerambycidae). Munis Entomology \& Zoololgy, 3(2); 707-715.

Pascoe, F. P., 1869. Longicornia Malayana: or a descriptive catalogue of the species of the three longicorn families Lamiidae, Cerambycidae and Prionidae collected by A. R. Wallace in the Malay Archipelago. (Part VII). The Transactions of the Entomological Society of London, (3) 3: 553-712.

Vives, E., 2003. Notes on Lepturinae (IX), new and interesting Lepturinae from East Asia (Coleoptera: Cerambycidae). Les Cahiers Magellanes, 31 : 1-16

Submitted: 15 October 2011, Accepted: 01 November 2011 Sectional Editor: Eduard Vives

H. V. Ghate ${ }^{1}$, C. A. Viraktamath ${ }^{2}$ and R. Sundararaj ${ }^{3}$

${ }^{\mathbf{1}}$ Department of Zoology, Modern College, Shivajinagar, Pune, India. E-mail: hemantghate@gmail.com

${ }^{2}$ Department of Entomology, Gandhi Krishi Vignyan Kendra, University of Agricultural Sciences, Bangalore, India.

${ }^{3}$ Wood Biodegradation Division, Institute of Wood Science \& Technology, $18^{\text {th }}$ cross, Malleswaram, Bangalore, India 